\title{
PENERAPAN FLOW SHOP SCHEDULLING PRODUKSI DI PT. ABHIJANA JAYA BRAJA SEJAHTERA
}

\author{
DARMADI \\ Universitas 45 Surabaya \\ Jl. Mayjend Sungkono 106 Surabaya \\ Irdarmadi56@gmail.com
}

\section{ABSTRAK}

$\mathrm{S}$ alah satu permasalahan dalam sistem produksi adalah mengatur penjadwalan kerja (jobs) agar kebutuhan konsumen terpenuhi. Oleh karena itu perusahaan PT Abhijana Jaya Braja Sejahtera dalam industri fasterner manufacktur adalah dengan menggunakan sistem penjadwalan flow shop, Karena penjadwalan dalam sistem flow shop ini akan lebih efisien sehingga memudahkan perusahaan untuk meminimumkan waktu pennyelesaian produksi secara keseluruhan. Data diambil dari catatan produksi perusahaan, hasil pengamatan didapatkan rata - rata 5.40 jam untuk memproduksi $100 \mathrm{~kg}$ / jam, setelah di analisa menunjukkan waktu normal 4.86 jam dibawah waktu standartnya 5.73 jam. Jadi Dari data yang diamati, dibuktikan bahwa waktu normal lebih rendah. sehingga metode flow shop schedulling menunjukkan efisien waktu secara signifikan.

Kata Kunci : penjadwalan flow shop, efisiensi.

\section{PENDAHULUAN}

Seiring berkembangnya teknologi otomotif dan pembangunan di Indonesia dari tahun ke tahun ternyata membawa pengaruh untuk industri pembuatan baut dan mur, Kondisi ini juga tidak biasa serta merta memberikan keuntungan yang maksimal kepada PT Abhijana Jaya Braja Sejahtera sebab dalam setiap elemen otomotif dan pembanguanan infrastruktur pasti ada baut dan mur sebagai unsur pengikatnya. Untuk memenuhi pesanan secara efisien dan efektif dibutuhkan sebuah proses produksi yang berjalan dengan lancar, perusahaan memerlukan suatu penjadwalan proses produksi yang baik pula. Dengan penjadwalan proses produksi yang terencana secara teratur, perusahaan tidak hanya dapat mempersingkat waktu tunggu pelanggannya, perusahaan tersebut juga dapat meningkatkan efisiensi dan efektivitas serta menghemat penggunaan sumber daya yang ada.

Dalam sebuah industri, baik itu industri manufaktur maupun jasa, adanya suatu proses penyusunan penjadwalan yang baik merupakan suatu hal yang sangat penting. Hal ini dikarenakan dengan adanya penjadwalan yang baik akan dapat meningkatkan efektivitas serta efisiensi sistem produksi. Penjadwalan dapat diartikan sebagai pengalokasikan sebagian pekerjaan dalam serangkaian mesin, setiap mesin hanya mengerjakan tidak lebih dari satu pekerjaan dalam satu waktu (Applegate dan cook, 1991).

Pada sistem produksi made-toorder (produksi dilakukan apabila terdapat pesanan), selain ukuran kualitas, ukuran tenggang waktu pengiriman (delivery due date) juga sangat penting bagi pelanggan (customer). Selain itu, tingkat efisiensi penggunaan (utilitas)fasilitas-fasilitas produksi 
seperti mesin, ruangan juga harus diperhatikan dalam analisis biaya dan waktu. Salah satu model yang dapat diterapkan dalam keadaan made-to-order pada perusahaan manufaktur adalah model penjadwalan flowshop. Dalam penjadwalanflowshop, terdapat sejumlah pekerjaan (job) yang tiaptiap job memiliki urutan pekerjaan mesin yang sama. Suatu penjadwalan dapat dimodelkan sebagai permasalahan penjadwalan flowshopapabila urutan pekerjaannya selaras. Urutan pekerjaan dikatakan selaras apabila urutan pekerjaan mesin tersebut dari satu job dengan job lainnya tidak terbalik. Pengurutan tersebut membutuhkan teknik yang paling tepat untuk membuat jadwal produksi yang paling baik, optimal, dan memenuhi segala kriteria seperti yang ditetapkan di perusahaan manufaktur.

Secara umum permasalahan yang di hadapi perusahaan dalam proses penyusunan penjadwalan adalah terbatasnya waktu untuk menyelesaikan proses produksi yang harus sesuai dengan waktu penyerahan yang diminta konsumen (due date), dimana setiap konsumen mempunyai waktu penyerahan yang berbeda - beda sementara perusahaan memiliki keterbatasan dalam hal tenaga kerja, mesin, dan kapasitas produksi. Adakalanya

\section{TINJAUAN PUSTAKA:}

\section{Pengertian Penjadwalan Proses Produksi}

Pengertian penjadwalan secara umum dapat diartikan seperti :"scheduling is the allocation of resources overtime to perform collection of risk ",yang artinya penjadwalan adalah pengalokasian perusahaan harus membayar biaya pinalti karena pesanan konsumen harus diselasaikan melebihi waktu yang telah ditentukan.

Oleh karena itu perusahaan harus dapat menentukan sistem penjadwalan yang tepat sesuai dengan situasi perasaingan dan strategi yang dijalankan oleh suatu perusahaan. Salah satu sistem penjadwalan dalam bidang industri adalah sistem penjadwalan flow shop.Karena penjadwalan dalam sistem flow shop ini akan lebih simpel dan kompleks sehingga memudahkan perusahaan untuk meminimumkan waktu pennyelesaian produksi secara keseluruhan.

\section{PerumusanMasalah}

Berdasarkan pada latar belakang tersebut di atas, maka permasalahan yang ditemukan yaitu:

Bagaimana penerapan flow shop scheduling pada mesin produksi mur pada satu siklus produksi diPT Abhijana Jaya Braja Sejahtera?

\section{Tujuan Penelitian}

Penelitian yang dilakukan pada PT Abhijana Jaya Braja Sejahterah bertujuan sebagai berikut:

Dapat mengetahui optimal waktu urutan

prosesdalammengerjakanpesanan

dengan penerapan flow shop scheduling.

sumber daya yang terbatas untuk mengerjakan sejumlah pekerjaan. Permasalahan muncul apabila pada tahapan operasi tertentu beberapa atau seluruh pekerjaan itu membutuhkan stasiun kerja yang sama. Dengan dilakukannya pengurutan pekerjaan ini unit-unit produksi (resources) dapat 
dimanfaatkan secara optimum. Pemanfaatan ini antara dilakukan dengan jalan meningkatkan utilitas unit-unit produksi melalui usahausaha mereduksi waktu menganggur (idle time) dari unit-unit yang bersangkutan. Pemanfaatan lainnya dapat juga dilakukan dengan cara meminimumkan in- process inventory melalui reduksi terhadap waktu rata-rata pekerjaan yang menunggu dalam baris antrian pada unit-unit produksi (Ginting $R$, 2009).

Pada pengalokasian sumber daya terdapat tujuan penting yang akan dicapai proses penjadwalan. Menurut (Bedworth,2002), terdapat dua target yang ingin dicapai melalui penjadwalan, yaitu jumlah output yang dihasilkan dan batas waktu penyelesaian yang telah ditetapkan (due date). Kedua target ini dinyatakan melalui kriteria penjadwalan seperti minimum makespan (keseluruhan waktu yang digunakan dalam proses produksi), minimum mean flow time (rata-rata waktu proses produksi), minimum mean lateness (rata-rata keterlambatan), minimum tardiness (keterlambatan), minimum mean tardiness (rata-rata keterlambatan), minimasi number of tardy (jumlah keterlambatan) dan sebagainya.

Menurut (Kenneth R, 2009) penjadwalan didefinisikan sebagai proses pengalokasian sumber sumber atau mesin - mesin yang ada untukk menjalankan sekumpulan tugas dalam jangka tertentu.Definisi lain, menurut (Conway, 2001). penjadwalan adalah proses pengurutan pembuatan produk secara menyeluruh pada sejumlah mesin tertentu dan pengurutan didefinisikan sebagai proses pembuatan produk pada satu mesin dalam jangka waktu tertentu. Input untuk suatu penjadwalan mencangkup urutan ketergantungan antar operasi, waktu proses untuk masing-masing operasi, serta fasilitas yang dibutuhkan oleh setiap operasi.

\section{Tujuan Penjadwalan Proses Produksi}

Penjadwalan Proses Produksi memiliki beberapa tujuan, hasil penjadwalan akan mendapatkan nilai yang lebih baik sesuai dengan yang diharapkan sebagai berikut :

1. Menurut Baker (1974)

a) Meningkatkan produktifitas mesin, yaitu dengan mengurangi waktu mesin menganggur.

b) Mengurangi persediaan barang setengah jadi dengan jalan mengurangi jumlah rata-rata pekerjaan yang menunggu dalam antrian suatu mesin karena mesin tersebut sibuk.

c) Mengurangi keterlambatan suatu pekerjaan. Setiap pekerjaan mempunyai batas waktu (due date) penyelesaian, jika pekerjaantersebut diselesaikan melewati batas waktu yang ditentukan maka pekerjaan tersebut dinyatakan terlambat. Dengan metoda penjadwalan maka keterlambatan ini dapat dikurangi, baik waktu maupun frekuensi.

2. Menurut Narasimhan (1985)

Penjadwalan yang baik seharusnya simpel, mudah dimengerti dan dapat dilaksanakan oleh pihak manajemen dan oleh siapapun yang menggunakannya. Aturan-aturan penjadwalan seharusnya cukup kuat tetapi mempunyai tujuan yang realistis sehingga cukup flexible untuk 
memecahkan masalah yang tidak terprediksi sebelumnya dan membolehkan satu perencanaan ulang.

Masalah penjadwalan muncul karena keterbatasan:

1. Waktu.

2. Tenga kerja.

3. Jumlah mesin.

4. Sifat dan syarat pekerja.

\section{Manfaat Penjadwalan}

Menurut (Baker, 2009) Adapun

manfaat penjadwalan proses

produksi termasuk:

1. Proses perubahan pengurangan terbesar.

2. Persediaan pengurangan yang bersifat meratakan.

3. Mengurangi upaya penjadwalan.

4. Peningkatan efisiensi produksi.

5. Meratakan beban buruh.

6. Tanggal pengiriman yang akurat.

7. Informasi yang besifat real time.

\section{Penjadwalan}

Menurut (Conway, 2001), masalah penjadwalan dapat diklasifikasikan berdasarkan beberapa faktor. Berikut dijelaskan faktor-faktor tersebut :

1. Jumlah mesin, berdasarkan jumlah mesin yang bekerja dibagi menjadi

dua bagian yaitu:

a) Penjadwalan pada mesin tunggal. b) Penjadwalan pada mesin ganda.

2. Sistem informasi, berdasarkan sistem informasi dibagi menjadi dua bagian yaitu:

a) Informasi bersifat deterministic.

b) Informasi bersifat stokastik. Informasi ini meliputi informasi yang berhubungan dengan karakteristikjob, yaitu saat kedatangan, batas waktu penyelesaian, perbedaan kepentingan di antara job-job yang dijadwalkan, banyaknya operasi, serta waktu proses tiap operasi. Disamping itu terdapat pula informasi yang menyangkut karakteristik mesin, seperti jumlah mesin, kapasitas, fleksibilitas serta efisiensi penggunaan yang berbeda untuk job yang berbeda.

3. Aliran proses, berdasarkan aliran proses dibagi menjadi tiga bagian yaitu :

Pureflowshop, general flowshop, dan jobshop. Berikut dijelaskan ketiga aliran proses tersebut :

a. Pure flowshop, pola aliran prosesnya identik. Setiap job melewati seluruh mesin yang bekerja dari proses awal hingga proses akhir sesuai dengan urutan.

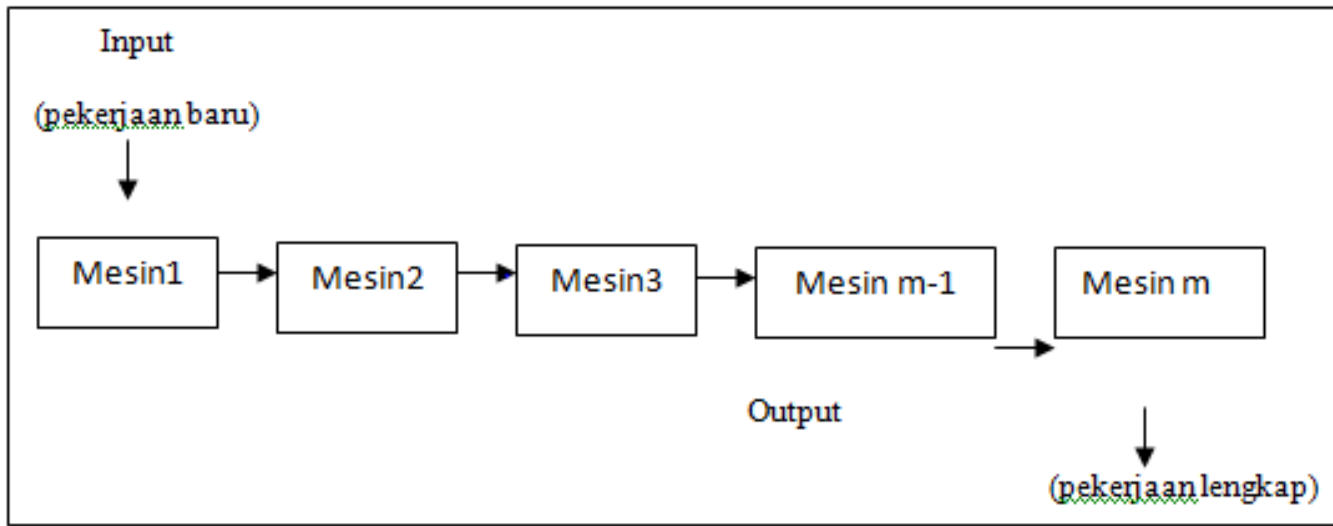


Gambar 1. Pola Aliran Pure Flow shop

Sumber : Baker (1974)

b. General flow shop, pola aliran prosesnya tidak identik. Masing-masing job tidak selalu melewati seluruh mesin yang bekerja.

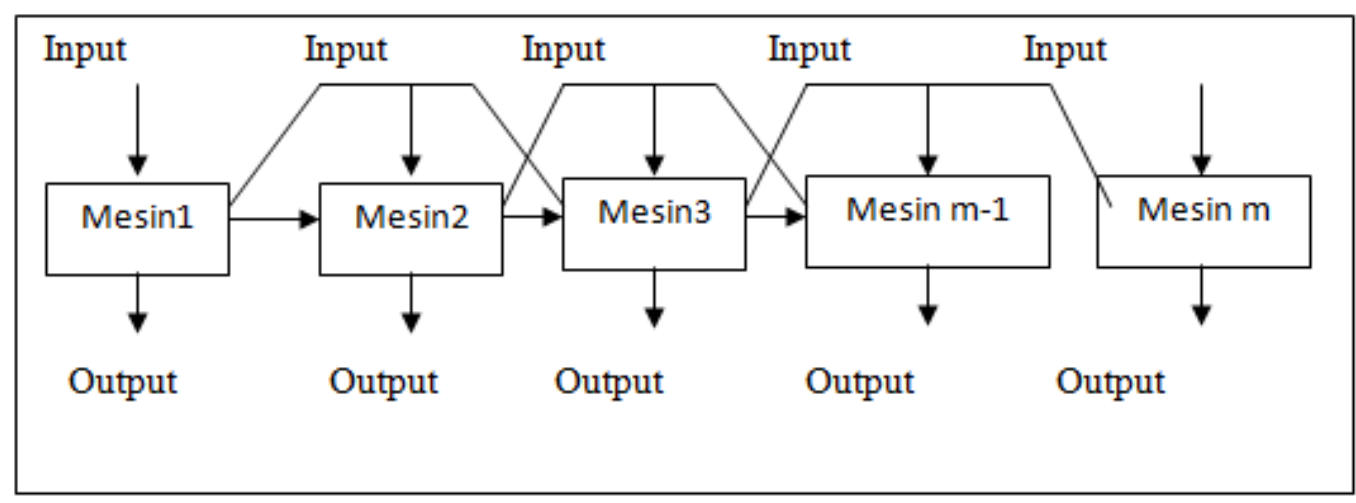

Gambar 2. Pola Aliran Pure Flow shop

Sumber : Baker (1974)

\section{Penjadwalan Flow shop}

Menurut Baker (1974), teknik penjadwalan Flow shop dapat dibagi ke dalam dua teknik, yaitu :

\section{Teknik Optimasi}

a. Algoritma Johnson untuk makespan.

b. Algoritma Branch and Bound.

\section{Teknik Heuristik}

Karakteristik Flow shop yang utama adalah adanya aliran mesin yang searah, waktu pengerjaan job dapat dilihat dengan membuat routing.

\section{Routing}

Suatu karakteristik utama dari disiplin penugasan adalah tipe mesin yang diperlukan untuk mengerjakan suatu job yang disebut routing. Job yang akan dijadwalkan, ditabulasikan kedalam table matriks routing mesin dan table matriks waktu proses.

Perbedaan antara Job shop dan Flow shop adalah pada matriks routing mesin dimana pada job shop matriks routing mesinnya tidak beraturan, sedangkan Flow shop beraturan. Perbedaannya dapat dilihat pada table-tabel dibawah ini :

Tabel 3. Contoh Matriks Waktu Proses Flow shop

\begin{tabular}{|c|c|c|c|}
\hline \multirow{2}{*}{} & \multicolumn{3}{|c|}{ Operasi } \\
\cline { 2 - 4 } Job1 & $\mathbf{1}$ & $\mathbf{2}$ & $\mathbf{3}$ \\
\hline Job2 & 2 & 3 & 4 \\
\hline Job3 & 3 & 4 & 3 \\
\hline
\end{tabular}

Tabel 4. Contoh Matriks Waktu Proses Job shop

\begin{tabular}{|c|c|c|c|}
\hline \multirow{2}{*}{} & \multicolumn{3}{|c|}{ Operasi } \\
\cline { 2 - 4 } & $\mathbf{1}$ & $\mathbf{2}$ & $\mathbf{3}$ \\
\hline Job1 & 2 & 3 & 4 \\
\hline Job2 & 2 & 4 & 3 \\
\hline Job3 & 3 & 2 & 4 \\
\hline
\end{tabular}

Tabel 5. Contoh Matriks Routing Mesin Flow shop

\begin{tabular}{|c|c|c|c|}
\hline \multirow{2}{*}{} & \multicolumn{3}{|c|}{ Operasi } \\
\cline { 2 - 4 } & $\mathbf{1}$ & $\mathbf{2}$ & $\mathbf{3}$ \\
\hline Job1 & 1 & 2 & 3 \\
\hline Job2 & 1 & 2 & 3 \\
\hline Job3 & 1 & 2 & 3 \\
\hline
\end{tabular}

Tabel 6. Contoh Matriks Routing Mesin Job shop

\begin{tabular}{|c|c|c|c|}
\hline \multirow{2}{*}{} & \multicolumn{3}{|c|}{ Operasi } \\
\cline { 2 - 4 } & $\mathbf{1}$ & $\mathbf{2}$ & $\mathbf{3}$ \\
\hline Job1 & 1 & 3 & 2 \\
\hline Job2 & 2 & 3 & 1 \\
\hline Job3 & 3 & 2 & 1 \\
\hline
\end{tabular}

Flow shop Scheduling. 
Proses penentuan urutan pengarjaan untuk suatu lintas produksi yang dapat digunakan beberapa jenis produk. ada beberapa operasi yang harus dilaksanakan dalam urutan tertentu serta satu pekerjaan mungkin membutuhkan maksimum satu operasi dimasing-masing mesin.

Karakteristik dasar penjadwalan flow shop iyalah sebagai berikut:

1. Terdapat $n$ job yang tersedia dan siap diproses pada waktu tertentu.

2. Waktu set up independent terhadap urutan pengerjaan.

3. Terdapat mesin berbeda, yang tersedia secara continue.

4. Operasi-operasi individual tidak dapat dipecah-pecah.

\section{Batch shop Scheduling.}

Sistem yang memproduksi banyak variasi produk dan volume, lama proses produksi untuk setiap produk agak pendek, dan satu lintasan produksi dapat dipakai untuk beberapa tipe produk. Pada sistem ini, pembuatan produk dengan tipe yang berbeda akan mengakibatkan pergantian peralatan produksi, sehingga sistem tersebut harus

\section{Proses Produksi Mur}

Proses produksi yang ada di perusahaan berikut :

Terdiri dari 2 proses mesin :

1. M1 Mesin Bolt Former: general purpose dan fleksibel untuk produk dengan volume yang rendah tetapi variasinya tinggi.

Penjadwalan produksi memiliki beberapa fungsi dalam sistem produksi, aktivitas-aktivitas tersebut iyalah (Teguh Baroto, 2002):

1. Loading (pembebanan) bertujuan mengkompromikan antara kebutuhan yang diminta dengan kapasitas yang ada. Loading ini untuk menentukan fasilitas, operator,dan peralatan.

2. Sequencing (penentuan urutan) bertujuan membuat prioritas pengerjaan dalam pemrosesan orderorder yangmasuk.

3. Dispatching (prioritas job) Pemberian perintah-perintah kerja ke tiap mesin atau fasilitas lainnya.

4. Updating Schedulling (perbarui jadwal)

Pelaksanaan jadwal biasanya selalu ada masalah baru yang berbeda dari saat pembuatan jadwal, maka jadwal harus segera di update bila ada permasalahan baru yang memang perlu diakomodasi.

PT.Abhijana Jaya Braja Sejahtera sebagai 


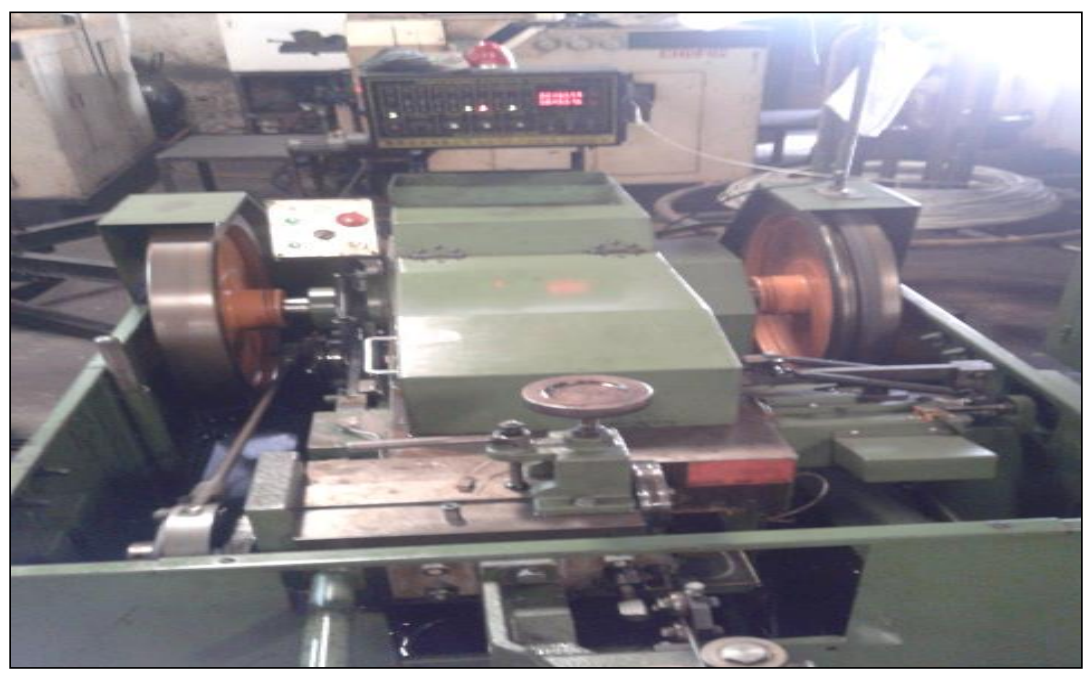

Gambar 3. Mesin Bolt Former

Mesin ini memproses mur dari mulai pemotongan, pembentukan mur dan pengeboran. Pada proses ini mur sudah jadi barang setengah jadi setelah itu proses berikutnya dilanjutkan ke mesin pengedratan.

2. M2 Mesin Drat :

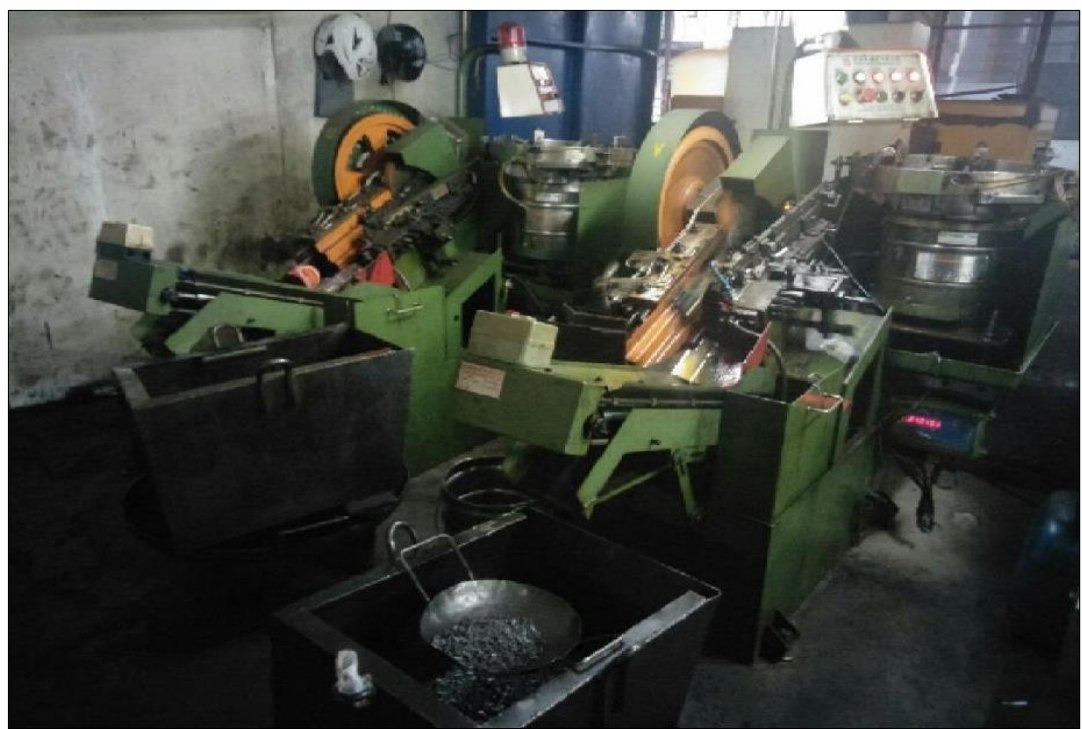

Gambar 4. Mesin Drat

Setelah melalui proses pada Mesin Boltformer lalu mur tersebut dimasukan kedalam mesin pengedratan untuk mengedrat bagian dalam mur, pada tahap ini mur sudah selesai dari proses produksi.

\section{Menentukan Waktu Normal}

Waktu normal merupakan waktu kerja yang telah mempertimbangkan factor penyesuaian, yaitu waktu siklus rata-rata dikalikan dengan factor prnyesuaian.Waktu normal untuk suatu elemen operasi kerja adalah semata-mata menunjukkan bahwa seorang operator yang berkualifikasi baik akan bekerja menyelesaikan pekerjaan pada tempo kerja yang normal (Wignjosoebroto, 2000).

Didalam praktek pengukuran kerja maka metoda penerapan rating performance kerja operator adalah didasarkan pada satu factor tunggal yaitu operator speed,space atau tempo. Sistem ini dikenal sebagai "performance Rating/speed Rating". Rating Faktor ini umumnya dinyatakan dalam persentase persentase (\%) atau angka decimal ,Dimana Performance kerja normal akan sama dengan $100 \%$ atau 1,00.

Rating factor pada umumnya diaplikasikan untuk menormalkan waktu 
kerja yang diperoleh dari pengukuran kerja akibat tempo atau pkecepatan kerja operator yang berubah-ubah.Untuk maksud ini, maka waktu normal dapat diperoleh dari rumus berikut :

Nilai waktu yang diperoleh disini masih belum bias kita tetapkan sebagai waktu baku untuk penyelesaian suatu operasi kerja,karena disini factor-faktor yang berkaitan dengan waktu kelonggaran (Allowance Time) agar operator bekerja sebaik-baiknya masih belum dikaitkan.

\section{Menentukan Waktu Baku / Standar}

Waktu standar adalah waktu yang sebenarnya digunakan operator untuk memproduksi satu unit dari data jenis produk. Waktu standar untuk setiap part harus dinyatakan termasuk toleransi untuk beristirahat untuk mengatasi kelelahan atau untuk factor-faktor yang tidak dapat dihindarkan. Namun jangka waktu penggunaannya waktu standard ada batasnya. Atau bisa dikatakan waktu yang dibutuhkan untuk mengerjakan atau menyelesaikan suatu aktivitas atau pekerjaan oleh tenaga kerja yang wajar pada situasi dan

\begin{tabular}{ccc} 
Waktu & \multicolumn{1}{c}{ Nomal $=\quad$ waktu } \\
pengamatan & x & $\frac{\text { Rating factor } \%}{100 \%}$
\end{tabular}

kondisi yang normal sehingga didapatkan waktu baku atau waktu standar secara umum.

Dengan demikian waktu baku tersebut dapat diperoleh dengan menagplikasikan rumus berikut.

Rumus (1) Merupakan Rumus sera umum yang paling banyak dipakai menghitung waktu baku, Meskipun sebenarnya rumus tersebut kurang teliti bilamana dibandingkan dengan rumus (2).

(1) $\mathrm{Wn}=\mathrm{Ws} \times \mathrm{p}$

$\mathrm{P}$ adalah faktor penyesuaian

1 siklus rata-rata normal, p1 untuk bekerjanya terlalu lambat atau sebaliknya..

Hitung waktu baku

(2) $\mathrm{Wb}=\mathrm{Wn}=(\mathrm{Wn} \times 1)$

Dimana 1 adalah kelonggaran atau allowance yang diberikan kepada pekerja untuk menyelesaikan pekerjaannya disamping waktu normal .

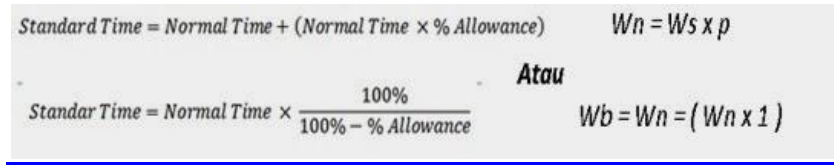

Pengukuran Waktu

Sistem pengukuran kerja praktis mencakup :

1. Pengukuran waktu aktual yang diobservasi

2. Penyesuaian waktu yang diobservasi untuk memperoleh "waktu normal" melalui pemeringkatan kerja

Cara menghitung waktu standar operasional produksi pada umumnya banyak ahli industri melihat dari waktu Standar adalah produk dari tiga faktor:

1. Waktu pengamatan (Obeserved Time) : Waktu yang diukur untuk menyelesaikan tugas.

2. Faktor penilaian kinerja (Rating Factor) : Kecepatan yang sedang dikerjakan orang. $90 \%$ bekerja lebih lambat dari biasanya, $110 \%$ bekerja lebih cepat dari biasanya, $100 \%$ normal. Faktor ini dihitung oleh seorang pekerja berpengalaman yang dilatih untuk mengamati dan menentukan peringkatnya.

3. Allowance pribadi, kelelahan, dan keterlambatan (PFD allowance). PFD (Personal, Figure dan Delay)allowance adalah penyesuaian yang dilakukan pada waktu normal untuk mendapatkan waktu standar bertujuan memulihkan waktu yang hilang karena kebutuhan pribadi, kelelahan, dan penundaan yang tidak dapat dihindari. Dengan 
memberikan sedikit peningkatan pada waktu normal di setiap siklus, pekerja masih dapat menutup waktu hilang dan menyelesaikan pekerjaan yang ditugaskan kepadanya.

\section{Menentukan}

Allowance

\section{(Kelonggaran) kerja}

Waktu longgar yang dibutuhkan dan akan menginterupsi proses produksi ini bisa diklasifikasikan menjadi personal allowance sekitar 2 sampai 5\% (10 sampai 24 menit), fatique allowance berkisar 5 sampai 15 menit, dan delay allowance. Pemberian waktu longgar dimaksudkan untuk memberi waktu kepada operator untuk menghentikan kerja, membutuhkan waktu-waktu khusus untuk kebutuhan pribadi, istirahat melepas lelah dan alasan-alasan lain di luar kontrolnya (Wignjosoebroto, 2008).

Besarnya kelonggaran yang diukur menggunakan ILO (International Labour Organization) Allowance dilihat dari beberapa faktor yaitu(Freivalds, 2009):

- $\quad$ Constant Allowance
Yaitu kelonggaran yang nilainya konstan atau tetap dan sudah distandarisasikan dilihat dari Personal Allowance (kelonggaran personal) sebesar $5 \%$ dan Basic Fatigue (tingkat kelelahan) sebesar $4 \%$.

\section{Variable Allowance}

Yaitu kelonggaran yang nilainya tidak tetap, dilihat dari pengamatan langsung secara aktual. Variable Allowance dilihat dari beberapa faktor yaitu: Faktor Standing Allowance (kelonggaran untuk pekerjaan yang posisinya berdiri) nilainya konstan yaitu $2 \%$, Faktor Abnormal Position (kelonggaran untuk posisi abnormal), Faktor tenaga yang dikeluarkan oleh masing-masing manpower dilihat dari kategori beban sehingga diberikan kelonggaran sebesar 0 - $22 \%$, Faktor Bad Light (cahaya yang buruk), Faktor Atmosphere Conditions (keadaan temperature tempat kerja), Faktor Noise Level (tingkat kebisingan), Faktor Mental Strain (ketegangan mental), Faktor Monotony (monoton),, Faktor Tediousness (kebosanan).Berikut ini adalah tabel perhitungan allowance kerja berdasarkan ILO Allowance: 
Tabel 7 Faktor Allowance Metode Westing house(Freivalds, 2009)

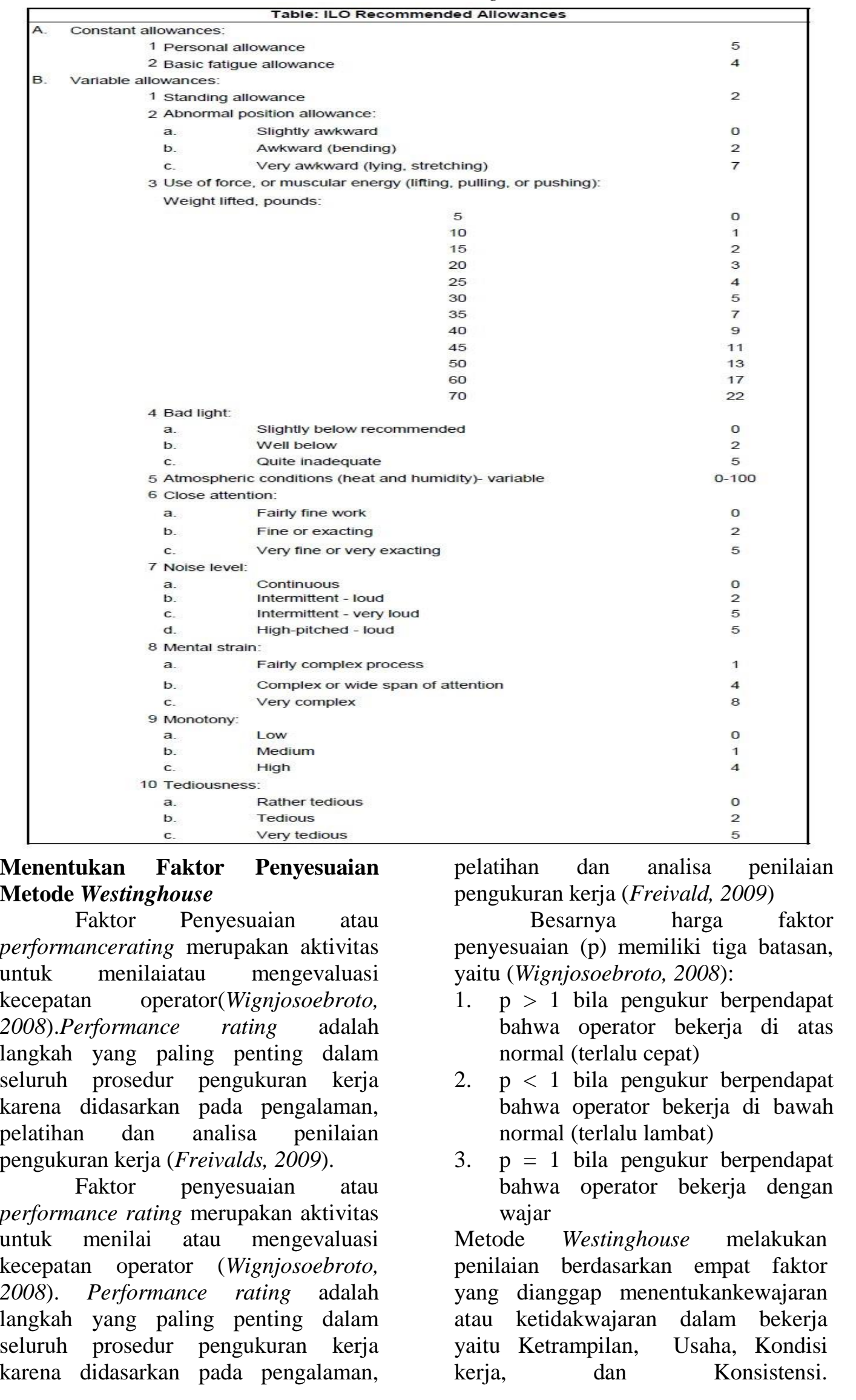


Setiapfaktorterbagikedalamkelaskelasdengannilainyamasingmasing.(Freivalds, 2009) :

1. Skill (kertrampilan) adalah kemampuan mengikuti metode kerja yang ditetapkan.

2. Effort (usaha) adalah kemauan untuk bekerja secara efektif.
3. Condition (usaha) adalah kondisi lingkungan kerja seperti suhu udara, adanya ventilasi udara, pencahayaan yang baik, dan kebisingan.

4. Consistency (konsistensi) adalah kenyataan bahwa setiap hasil pengukuran waktu menunjukkan yang berbeda:

Tabel 7 Faktor Penyesuaian Metode Westinghouse(Freivalds, 2009)

\begin{tabular}{|c|c|c|c|}
\hline Faktor & Kelas & Lambang & Penyesuaian \\
\hline \multirow[t]{11}{*}{ Keterampilan } & Superskill & A1 & +0.15 \\
\hline & & A.2 & +0.13 \\
\hline & Excollent & B1 & +0.11 \\
\hline & & B2 & +0.08 \\
\hline & Good & $c_{1}$ & +0.08 \\
\hline & & $\mathrm{C} 2$ & +0.03 \\
\hline & Average & D & 0.00 \\
\hline & Fair & $\mathrm{E}_{1}$ & -0.05 \\
\hline & & E2 & -0.10 \\
\hline & Poor & $\overrightarrow{F 1}$ & -0.16 \\
\hline & & $F 2$ & -0.22 \\
\hline \multirow[t]{11}{*}{ Usaha } & Excoessive & A1 & +0.13 \\
\hline & & $A 2$ & +0.12 \\
\hline & Excollent & B1 & +0.10 \\
\hline & & $\mathrm{B} 2$ & +0.08 \\
\hline & Good & $C_{1}$ & +0.05 \\
\hline & & $\mathrm{C} 2$ & +0.02 \\
\hline & Average & D & 0.00 \\
\hline & Fair & E1 & -0.04 \\
\hline & & E2 & -0.08 \\
\hline & Poor & $F_{1}$ & -0.12 \\
\hline & & $F 2$ & -0.17 \\
\hline \multirow[t]{6}{*}{ Kondisi Kerja } & Ideal & A & +0.08 \\
\hline & Excollent & B & +0.04 \\
\hline & Good & c & +0.02 \\
\hline & Average & D & 0.00 \\
\hline & Fair & E & -0.03 \\
\hline & Poor & $\mathrm{F}$ & -0.07 \\
\hline \multirow[t]{6}{*}{ Konsistensi } & Perfect & A & +0.04 \\
\hline & Excollent & B & +0.03 \\
\hline & Good & c & +0.01 \\
\hline & Average & D & 0.00 \\
\hline & Fair & $\mathrm{E}$ & -0.02 \\
\hline & Poor & $\mathrm{F}$ & -0.04 \\
\hline
\end{tabular}

\section{Data Produksi}

Berikut ini adalah data produksi flow shop berdasarkan permintaan produk
Mur dan ukuran pada bulan September 2017 di perusahaan PT.Abhijana Jaya Braja Sejahtera, sebagai berikut :

Tabel 8 Data Produksi Mur Yang Dihasilkan

\begin{tabular}{|l|l|l|l|l|l|l|}
\hline \multirow{2}{*}{ No. } & \multirow{2}{*}{ No. MESIN } & \multicolumn{2}{|l|}{ UKURAN } & \multicolumn{2}{l|}{$\begin{array}{l}\text { Produksi } \\
\text { Mesin }\end{array}$} & $\begin{array}{l}\text { Produksi 100 } \\
\text { Kg }\end{array}$ \\
\cline { 3 - 7 } & & \multicolumn{2}{|l}{} & & \\
\cline { 3 - 7 } & & $\mathrm{M}$ & & Kunci & $\mathrm{kg} / \mathrm{jam}$ & Jam \\
\hline 1 & EA-003 & M5 X P0,8 & Metris & 8 & 8,65 & 11,56 \\
\hline 3 & EA-009 & W3/16 X 24T & Kotak & 8 & 7,96 & 12,57 \\
\hline 3 & EA-001 & M6 X P1,0 & Metris & 10 & 18,45 & 5,42 \\
\hline
\end{tabular}




\begin{tabular}{|l|l|l|l|l|l|l|}
\hline 4 & EA-002 & M6 X P1,0 & Metris & 10 & 17,22 & 5,81 \\
\hline 5 & EA-004 & M6 X P1,0 & Metris & 10 & 18,45 & 5,42 \\
\hline 6 & ED-007 & W1/4 X 20T & Kotak & 11 & 13,32 & 7,51 \\
\hline 7 & EA-012 & M8 X P1,25 & Metris & 12 & 29,25 & 3,42 \\
\hline 8 & EA-011 & M8 X P1,25 & Metris & 12 & 29,25 & 3,42 \\
\hline 9 & EA-010 & M8 X P1,25 & Metris & 12 & 29,25 & 3,42 \\
\hline 10 & EA-006 & M8 X P1,25 & Metris & 13 & 36,00 & 2,78 \\
\hline 11 & ED-008 & W3/8 X 16T & Inch & 14 & 38,28 & 2,61 \\
\hline 12 & EA-005 & W1/2 X 12T & Inch & 19 & 121,92 & 0,82 \\
\hline
\end{tabular}

\section{Perhitungan Waktu Normal dan Waktu Standart}

Maka waktu normal dan waktu standar dari data diatas sebagai berikut:

Tabel 9 Data Rata - Rata Produksi Mur Yang Dihasilkan

\begin{tabular}{|l|l|l|l|}
\hline \multirow{2}{*}{ No. } & \multirow{2}{*}{ No. MESIN } & UKURAN & $\begin{array}{l}\text { Produksi 100 } \\
\text { Kg / jam }\end{array}$ \\
\cline { 3 - 4 } & & M & \\
\hline 1 & EA-003 & M5 X P0,8 & 11,56 \\
\hline 2 & EA-009 & W3/16 X 24T & 12,57 \\
\hline 3 & EA-001 & M6 X P1,0 & 5,42 \\
\hline 4 & EA-002 & M6 X P1,0 & 5,81 \\
\hline 5 & EA-004 & M6 X P1,0 & 5,42 \\
\hline 6 & ED-007 & W1/4 X 20T & 7,51 \\
\hline 7 & EA-012 & M8 X P1,25 & 3,42 \\
\hline 8 & EA-011 & M8 X P1,25 & 3,42 \\
\hline 9 & EA-010 & M8 X P1,25 & 3,42 \\
\hline 10 & EA-006 & M8 X P1,25 & 2,78 \\
\hline
\end{tabular}




\begin{tabular}{|l|l|l|l|}
11 & ED-008 & W3/8 X 16T & 2,61 \\
\hline 12 & EA-005 & W1/2 X 12T & 0,82 \\
\hline \multirow{2}{*}{} & & Total & 64,75 \\
\cline { 3 - 4 } & Rata - rata & 5,40 \\
\cline { 3 - 3 } & &
\end{tabular}

Dimana :

1. Rata - rata waktu pengamatan :

Dari 12 job data tabel di atas, menghasilkan catatan waktu (100kg / jam) :

$11.56+12.57+5.42+5.81+5.42+7.51+3.42+3.42+3.42+2.78+2.61+0.82=$

$\frac{64,75}{12}=5,40 \mathrm{jam}$

2. Rating factor:

Menurut Debrina Puspita(2014) yang mengutip Wignjosoebroto'(2006), Rating Factor bisa dihitung dengan menggunakan metode Westinghouse. Routing Factor bisa ditentukan melalui 4 faktor yaitu : skill, usaha, kondisi kerja, dan konsistensi. Seperti terlihat pada tabel dibawah ini.

Tabel 10 Penyesuaian Kelonggaran Menurut WestingHouse

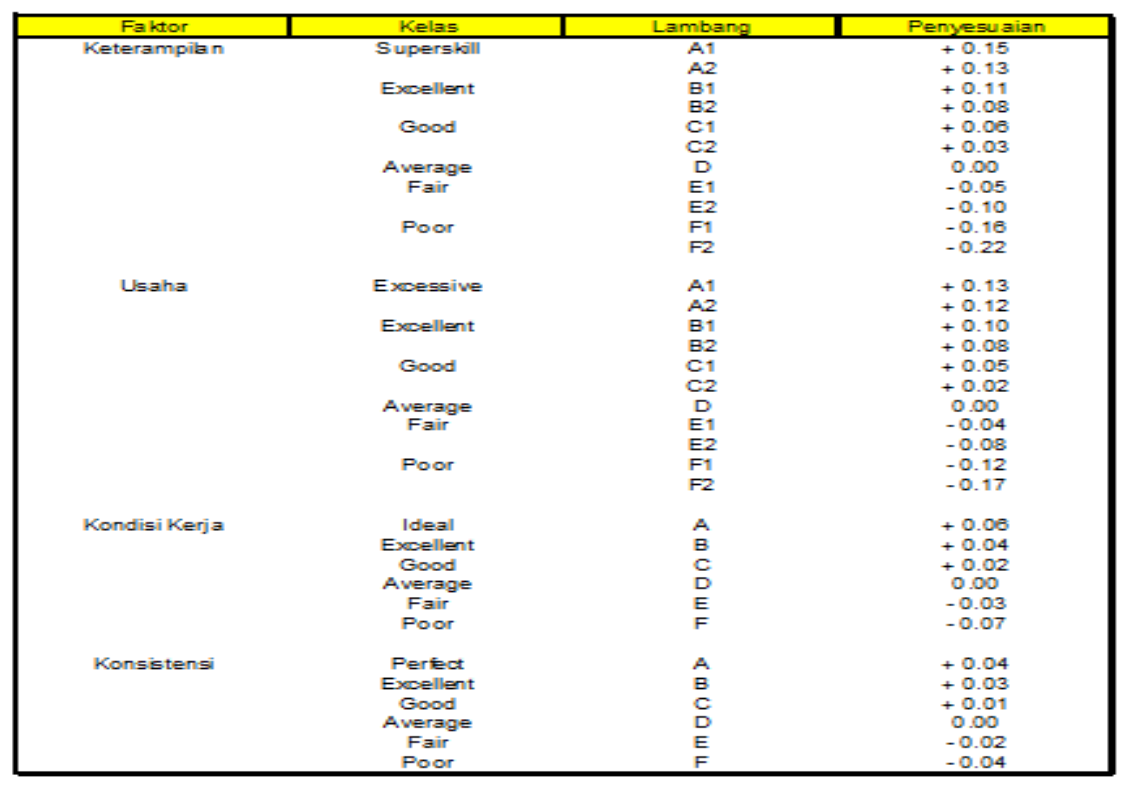

Pada PT. Abhjana Jaya Braja Sejahtera ditentukan sebagai berikut :
1. Skill
$=$ Average
$\mathrm{D}=0.00$
2. Usaha
$=$ Fair
E2 $=-0.08$
3. Kondisi kerja
$=$ Average
$\mathrm{D}=0.00$
4. Konsistensi
$=$ Fair
E $\quad=-0.02+$

Jadi $\mathrm{P}=1+(-0.10)=0.9=90 \%$ 
3. Allowances:

PT. Abhijana Jaya Braja Sejahtera menentukan bahwa dalam delapan jam seorang karyawan bekerja, kelonggaran waktu untuk kebutuhan pribadi ini 72 menit (1.2 jam) dengan rincian sebagai berikut :

1. Istirahat $=30$ menit

2. Sholat $=17$ menit

3. Makan, dll $=25$ menit

sehingga allowances $($ kelonggaran $)=\frac{1.2 \mathrm{jam}}{8 \mathrm{jam}}=15 \%$

jadi waktu normal dan waktu standartnya sebagai berikut :

Waktu Normal

$$
\begin{aligned}
& =\text { rata }- \text { rata pengamatan } \times \frac{\text { rating factor } \%}{100 \%} \\
& =5.40 \times \frac{90 \%}{100 \%} \\
& =5.40 \times 0.9 \\
& =4.86 \mathrm{jam}
\end{aligned}
$$

Waktu Standard $=$ waktu normal $\mathrm{x} \frac{100 \%}{100 \%-\text { allowance }}$

$$
\begin{aligned}
& =4.86 \times\left(\frac{100 \%}{100 \%-15 \%}\right) \\
=4.86 \times & \times\left(\frac{100 \%}{85 \%}\right) \\
= & 4.86 \times 1.18 \\
& =5.73 \mathrm{jam}
\end{aligned}
$$

\section{KESIMPULAN DAN SARAN}

\section{Kesimpulan}

Data yang diperoleh :

1. Rata - rata waktu pengamatan $=5.40 \mathrm{jam}$.

2. Waktu Normal

$$
=4.86 \mathrm{jam} \text {. }
$$

3. Waktu Standart

$$
=5.73 \mathrm{jam} \text {. }
$$

Maka dibuktikan bahwa waktu normal lebih rendah dari pada waktu standart. Sehingga metode flow shop schedulling yang diterapkan di PT.Abhijana Jaya Braja Sejahtera bisa mengetahui optimal waktu produksi menunjukkan efisiensi waktu secara signifikan.

\section{Saran}

1. Penelitian lebih lanjut terhadap analisa flow shop schedulling dengan spesifikaksi job yang sama dan pengulangan yang cukup.

2. Penelitian lebih lanjut terhadap analisa flow shop schedulling dengan job yang berbeda. 


\section{DAFTAR PUSTAKA}

Buku Profil PT Abhijana Jaya Braja Sejahtera.

Biegel,John E, (1978), "Production Control : A Quantitive Approach", Prentice Hall Of India Private Limited, New Delhi.

Baker, Kenneth R, (1984), “ Introduction To Sequencing and Scheduling" Jhon Wiley \& Sound, New York.

Baroto, Teguh., (2002),"Perencanaan dan Pengendalian Produksi" Bab 6, Penjadwalan Produksi.

Baker, Kenneth R. (1974),"Introduction To Sequencing And Scheduling. New York.

Ginting, Rosnani (2007), "Sistem Produksi”. Graha ILmu. Jakarta.

Ginting, Rosnani. (2009),"Penjadwalan Mesin”. Yogyakarta: PT. Graha ilmu.

Hendra Kusuma (2009),“Manajemen produksi Perencanaan \& Pengendalian Produksi", CV, Andi Offset, Yogyakrta.

Harding. (1978),“Manajemen Produksi", Lembaga Ppm-Balai Aksara, Jakarta.

Murdifin Haming Dan Mahfud Nurnajamuddin.

(2012), "Manajemen Produksi ModernOperasi Manufactur Dan Jasa”, Bumi Aksara, Jakarta.

Pangestu Subagyo. (2009),“Manajemen Operasi Edisi". I, BPFE, Yogyakarta.

Supriyanto. (2008),"Penjadwalan Pekerjaan Pada Fleksible Flowshop Dengan KriteriaMinimasi Mean Tardiness "Surakarta:Universitas Negeri Sebelas Maret.

Sritomo Wignjosoebroto. (2003), "Pengantar Teknik Industri \& Managemen Industri". Institut Teknologi Sepuluh November, Surabaya.

Sugiyono. (2010),"Metode Penelitian Kuantitatif, Kualitatif”. Bandung: CV.Alfabeta
Westinghouse Company. (1927),

“Westing house System's Rating". 
Darmadi / MATRIK Vol. XX. No 1 September 2019 p:13-28

(Halaman ini sengaja dikosongkan) 